\title{
Kualitas Air Rawa terhadap Keluhan Kesehatan Masyarakat Desa
}

\section{The Quality of Water Swamp on Complaints Health Villagers}

\author{
Norsita Agustina ${ }^{1,}$ Chandra $^{2}$, Muhammad Febriza Aquarista ${ }^{3}$ \\ Fakultas Kesehatan Masyarakat, Universitas Islam Kalimantan (UNISKA) MAB Banjarmasin, Indonesia
}

\section{ARTICLE INFO}

\section{Article history}

Received date 18 May 2021

Revised date

14 Jun 2021

Accepted date

12 Jul 2021

\section{Keywords:}

Health complaints;

Swamp water;

Water quality.

\section{Kata kunci:}

Keluhan kesehatan;

Air rawa;

Kualitas air.

\begin{abstract}
ABSTRAK
Swamp water is the source of water used Banyu Hirang Village community. The research objective is to analyze the turbidity, levels of iron and organic matter content, and community health complaints. Sampling by purposive proportional random sampling 34 people. Swamp water sampling points were carried out at 7 points, 3 from dug wells and 4 from drilled wells. Data examination of water quality in the form of turbidity, levels of iron, and organic matter content through laboratory testing in Research and Industry Standards (BARISTAND) Banjarbaru. While data with a health complaint questionnaire interviews. The study states examination physical and chemical parameters in swamp water wells exceeded the threshold-based Permenkes No.32/2017 with a maximum standard of $25 \mathrm{NTU}$, iron there are 2 points whose threshold value is less than the maximum limit of $10 \mathrm{mg} / \mathrm{L}$. In drilled wells with physical parameters of turbidity at 4 points less than the threshold, for iron at 4 points less than the threshold of $1,0 \mathrm{mg} / \mathrm{L}$ and organic matter, there are 3 points where the threshold value is less than the maximum limit of $10 \mathrm{mg} / \mathrm{L}$, while 1 point of $12,86 \mathrm{mg} / \mathrm{L}$ exceeds the threshold. For health complaints, there are $12 \%$ of respondents experience health complaints of red skin, $73 \%$ have complaints of itchy skin and $15 \%$ have scaly skin. Suggestions to improve health promotion, especially about the importance of treating water before use and immediately swamp allocate construction of water supply to avoid the risk of health problems.
\end{abstract}

Air rawa merupakan sumber air yang digunakan masyarakat Desa Banyu Hirang. Tujuan penelitian adalah menganalisis kekeruhan, kadar zat besi dan kandungan zat organik dan keluhan kesehatan masyarakat. Pengambilan sampel secara purposive proportional random sampling berjumlah 34 orang di Desa Banyu Hirang. Titik pengambilan sampel air rawa dilakukan pada 7 titik, 3 titik dari sumur gali dan 4 titik dari sumur bor. Data pemeriksaan kualitas air berupa kekeruhan, kadar besi dan kandungan zat organik melalui uji laboratorium di Balai Riset dan Standarisasi Industri (BARISTAND) Kota Banjarbaru. Sedangkan data keluhan kesehatan dengan wawancara menggunakan kuesioner. Hasil penelitian menyatakan pemeriksaan parameter fisik dan kimia pada air rawa sumur gali melebihi ambang batas berdasarkan Permenkes No.32/2017 dengan standar maksimal 25 NTU, pada zat besi terdapat 2 titik yang nilai ambang batas kurang dari batas maksimal 10mg/L. Pada sumur bor dengan parameter fisik pada kekeruhan di 4 titik kurang dari ambang batas, pada zat besi di 4 titik kurang dari ambang batas sebesar 1,0mg/L dan Zat Organik ada 3 titik yang nilai ambang batas kurang dari batas maksimal $10 \mathrm{mg} / \mathrm{L}$, sedangkan 1 titik sebesar $12,86 \mathrm{mg} / \mathrm{L}$ melebihi ambang batas. Untuk keluhan kesehatan terdapat $12 \%$ responden yang mengalami keluhan kesehatan kulit menjadi merah, $73 \%$ mengalami keluhan kulit gatal-gatal dan $15 \%$ mengalami kulit bersisik. Saran untuk meningkatkan promosi kesehatan khususnya tentang pentingnya mengolah air rawa sebelum dipergunakan dan segera mengalokasikan pembangunan sarana air bersih untuk menghindari risiko gangguan kesehatan.

Corresponding Author:

Norsita Agustina

Fakultas Kesehatan Masyarakat, Universitas Islam Kalimantan (UNISKA) MAB Banjarmasin, Indonesia

Email: norsita.agustina@gmail.com

\section{PENDAHULUAN}

Air merupakan kebutuhan esensial dalam kehidupan tampak dari kebutuhan terhadap air untuk keperluan sehari-hari di lingkungan rumah tangga ternyata berbeda-beda di setiap tempat, setiap tingkatan kehidupan atau setiap bangsa dan negara. Semakin tinggi taraf kehidupan seseorang 
semakin meningkat pula kebutuhan manusia akan air (Hapsari, 2015). Air rawa merupakan limbah yang memiliki kandungan logam Fe, Mn dan mikroorganisme berbahaya.Turbidity atau kekeruhan dari air disebabkan oleh adanya partikel-partikel dalam air atau suspended yang larut tetapi berwarna atau juga dapat dikelompokkan kedalam zat organik dan nonorganik, plankton serta mikroorganisme lainnya (Agmalini, Lingga dan Nasir, 2013).

Keberadaan desa Banyu Hirang masih sedikit yang menggunakan sumber air bersih karena daerah dataran rendah sehingga air yang didapat di desa ini adalah air rawa. Keadaan air rawa tersebut secara fisik berwarna coklat dan banyak terdapat alga di sekitar rawa. Sehingga masih banyak responden langsung ke air rawa untuk mencuci, mandi dan mengambil air untuk memasak dan minum.

Hasil studi menunjukkan warna, kesadahan total, mangan, $\mathrm{pH}$, sulfat dan zat organik air sumur gali dan kadar sulfat sumur bor telah melebihi baku mutu baik sebagai sumber air bersih maupun air minum. Pengukuran kualitas air secara fisik dan kimia pada air sumur gali dan sumur bor menjadi kebutuhan sebagai upaya pencegahan dan pengendalian penyakit yang disebabkan oleh air yang tidak memenuhi syarat kesehatan (Munfiah, Nurjazuli dan Setiani, 2013). Air yang kualitasnya buruk akan mengakibatkan kondisi lingkungan hidup menjadi buruk.

Pemeriksaan kualitas air sumur gali di Desa Gaji diperoleh Kadar pH sebesar 6,49 (baku mutu pH 6,5-9,0), sulfat $\left(\mathrm{SO}_{4}\right) 527,47 \mathrm{mg} / \mathrm{L}$ (baku mutu $\left.\mathrm{SO}_{4} 400 \mathrm{mg} / \mathrm{L}\right)$, dan zat organik $\left(\mathrm{KMnO}_{4}\right)$ sebesar 10,25mg/L (baku mutu zat organik $10 \mathrm{mg} / \mathrm{L})$. Hasil studi pendahuluan menunjukan warna, kesadahan total, mangan, $\mathrm{pH}$, sulfat dan zat organik pada air sumur gali dan kadar sulfat sumur bor telah melebihi baku mutu baik sebagai sumber air bersih maupun air minum (Munfiah, Nurjazuli dan Setiani, 2013).

Tidak hanya dari segi kualitas fisik saja tetapi dari segi kualitas mikrobiologis dan kimia, air gambut tersebut tidak memenuhi syarat kesehatan. Bayangkan apabila air tersebut dikonsumsi dalam waktu yang relatif lama. Hal ini dapat menyebabkan keluhan kesehatan bagi masyarakat setempat, bukan hanya efek secara langsung tetapi juga efek secara kumulatif akibat dari kandungan yang terdapat pada air tersebut (Suhendra, Marsaulina dan Santi, 2013). Penggunan air yang tidak memenuhi persyaratan dapat menimbulkan gangguan kesehatan. Gangguan kesehatan tersebut berupa penyakit menular maupun tidak menular. Penyakit menular disebabkan oleh air secara langsung yang sering dikenal penyakit bawaan air (water borne diseases). Penyakit tidak menular akibat penggunaan air terjadi karena air telah terkontaminasi zat-zat berbahaya atau beracun.

\section{METODE}

Penelitian ini dilakukan di Desa Banyu Hirang Kecamatan Gambut Kabupaten Banjar yang merupakan daerah dataran rendah dan berawa. Lokasi ini cukup terpencil jauh dari kota. Jarak yang jauh menyebabkan diperlukan waktu lebih dari 1,5 jam untuk dapat sampai di desa ini. Ditambah lagi fasilitas jalan yang rusak dan sulit ditempuh dengan mobil terlebih ketika sudah musim hujan. Jalan untuk menuju desa ini rusak parah dan berlumpur sehingga kendaraan roda dua sulit untuk menempuh perjalanan menuju desa ini. Tidak jarang juga desa ini banjir ketika sudah hujan lebat. Fasilitas jalan yang masih tanah, belum di aspal dengan batu-batu yang besar yang terletak di sekitar jalan menambah kesulitan untuk sampai ke desa ini.

Keberadaan desa ini masih sebagian yang menggunakan sumber air bersih karena daerah dataran rendah sehingga air yang didapat di desa ini adalah air rawa. Keadaan air rawa tersebut secara fisik berwarna coklat dan banyak terdapat alga di sekitar rawa. Sehingga masih banyak responden langsung ke air rawa untuk mencuci, mandi dan mengambil air untuk memasak dan minum.

Jenis penelitian bersifat survei deskriptif. Populasi penelitian ini adalah seluruh masyarakat yang meenggunakan air rawa sebagai kebutuhan sehari-hari bejumlah 2560 Kepala Keluarga di Desa Banyu Hirang Kecamatan Gambut. Teknik pengambilan sampel yang digunakan peneliti adalah purposive proportional random sampling. Purposive sampling. Sampel yang digunakan peneliti dalam penelitian menggunakan rumus Slovin Sehingga diperoleh sampel sebanyak 34 responden. Sedangkan pengambilan sumber air yang digunakan masyarakat di Desa Banyu Hirang, sumber air yang digunakan adalah air sumur gali dan air sumur bor di rumah warga didampingi oleh petugas laboratorium. Pengambilan sampel dilakukan di 3 titik air sumur gali dan 4 titik air sumur bor di rumah warga kemudian sampel air dibawa ke Balai Riset dan Standarisasi Industri kota Banjarbaru untuk dilakukan pemeriksaan kualitas air berupa kualitas fisik (kekeruhan), kualitas kimia (kadar besi $(\mathrm{Fe})$ dan kandungan zat organik (KMnO4)). Hasil pemeriksaaan air kemudian dibandingkan dengan Permenkes No. 32/2017 tentang Tentang 
Standar Baku Mutu Kesehatan Lingkungan Dan Persyaratan Kesehatan Air Untuk Keperluan Higiene Sanitasi, Kolam Renang, Solus Per Aqua, Dan Pemandian Umum. Namun ada beberapa pertanyaan terkait karakteristik penggunaan air rawa seperti sumber air yang digunakan, pemanfaatan air rawa dan cara pengolahan sebelum menggunakan air rawa. Analisis dilakukan univariat untuk mendeskripsikan semua variabel sebagai bahan informasi dengan menggunakan tabel distribusi frekuensi untuk mengetahui analisis kualitas air rawa terhadap keluhan kesehatan pada masyarakat Desa Banyu Hirang Kecamatan Gambut. Penelitian ini telah lolos Uji Etik dari Komite Etik Lembaga Penelitian dan Pengabdian Kepada Masyarakat Universitas Islam Kalimantan Muhammad Arsyad Al Banjari Banjarmasin dengan Nomor: 017/UNISKALPPM/I/2020.

\section{HASIL}

\begin{tabular}{ccc}
$\begin{array}{c}\text { Tabel 1. Karakteristik } \\
\text { Berdasarkan } \\
\text { Pekerjaan }\end{array}$ & Jenis & \multicolumn{2}{c}{$\begin{array}{c}\text { Responden } \\
\text { Kelamin }\end{array}$} \\
\hline Variabel & n & \% \\
\hline $\begin{array}{c}\text { Jenis Kelamin } \\
\text { Laki-Laki }\end{array}$ & 10 & 29,5 \\
Perempuan & 24 & 70,5 \\
Pekerjaan & & \\
Tidak bekerja & 26 & 76,5 \\
Bekerja & 8 & 23,5 \\
\hline
\end{tabular}

Tabel 1 menunjukan bahwa dari 34 responden yang menjadi sampel penelitian sebanyak 70,5\% adalah perempuan dan $29,5 \%$ laki-laki. Untuk Variabel pekerjaan terdapat sebanyak $70,5 \%$ adalah bekerja dan $76,5 \%$ tidak bekerja.

Tabel 2. Karakteristik Responden dalam Penggunaan Air Rawa

\begin{tabular}{lrr}
\hline \multicolumn{1}{c}{ Karakteristik Penggunaan Air } & n & \% \\
\multicolumn{1}{c}{ Rawa } & & \\
\hline Sumber air yang digunakan & & \\
$\quad$ Sumur Gali & 21 & 62 \\
$\quad$ Sumur Bor & 10 & 30 \\
PDAM & 3 & 8 \\
$\begin{array}{l}\text { Penggunaan Air Rawa } \\
\quad \text { Air minum, mandi dan mencuci }\end{array}$ & 10 & 30 \\
$\quad$ Mandi & 9 & 26 \\
$\quad$ Mencuci dan mandi & 15 & 44 \\
Cara pengolahan $\quad$ sebelum & & \\
menggunakan air rawa & & \\
$\quad$ Dipakai langsung & 5 & 15 \\
$\quad \begin{aligned} \text { Diendapkan terlebih dahulu } \\
\text { Disaring terlebih dahulu }\end{aligned}$ & 25 & 73 \\
\hline
\end{tabular}

Tabel 2 menunjukan bahwa dari 34 responden yang menjadi sampel penelitian sebanyak 21 responden (62\%) yang menggunakan sumur gali, 10 responden (30\%) yang menggunakan sumur bor dan sebanyak 3 responden (8\%) yang menggunakan PDAM. Penggunaan air rawa sebanyak 10 responden (30\%) yang menggunakan sebagai air minum, mandi dan mencuci, 9 responden (26\%) yang menggunakan sebagai mandi dan sebanyak 15 responden $(44 \%)$ yang menggunakan air rawa sebagai mencuci dan mandi. Cara pengolahan sebelum menggunakan air rawa sebanyak 5 responden (15\%) yang dipakai langsung, 25 responden $(73 \%)$ diedapkan terlebih dahulu dan sebanyak 4 responden (12\%) yang disaring dahulu air rawa tersebut.

Tabel 3. Keluhan Kesehatan Pengguna Air Rawa

\begin{tabular}{lrr}
\hline Keluhan Kesehatan & n & $\%$ \\
\hline Kesehatan Kulit & & \\
$\quad$ Kulit menjadi merah & 4 & 12 \\
$\quad$ Gatal-gatal & 25 & 73 \\
$\quad$ Kulit bersisik & 5 & 15 \\
Kesehatan Pencernaan & & \\
$\quad$ Mual & 4 & 12 \\
$\quad$ Diare & 20 & 59 \\
$\quad$ Tidak merasakan keluhan & 10 & 29 \\
\hline
\end{tabular}

Tabel 3 menunjukan bahwa dari 34 responden yang menjadi sampel penelitian sebanyak 4 responden (12\%) yang mengalami keluhan kesehatan pada kulit menjadi merah, 25 reponden $(73 \%)$ yang mengalami keluhan kesehatan pada kulit gatal-gatal, 5 responden (15\%) mengalami ganguan kesehatan pada kulit bersisik. Keluhan kesehatan pada pencernaan sebanyak 4 responden (12\%) yang mengalami mual, 20 responden (59\%) mengalami diare dan sebanyak 10 responden (29\%) yang tidak merasakan keluhan. 
Tabel 4. Hasil pemeriksaan Parameter Fisik dan Kimia pada air rawa Sumur Gali berdasarkan Kekeruhan, Kadar Besi (Fe), dan Kandungan Zat Organik (KMnO4)

\begin{tabular}{|c|c|c|c|c|c|}
\hline \multirow{2}{*}{ Paramaeter } & \multirow{2}{*}{ Satuan } & \multirow{2}{*}{$\begin{array}{c}\text { Syarat Mutu Permenkes } \\
\text { No. 32/2017 }\end{array}$} & \multicolumn{3}{|c|}{ Sampel Air Rawa (Sumur Gali) } \\
\hline & & & Titik 1 & Titik 2 & Titik 3 \\
\hline Parameter Fisik & & & & & \\
\hline Kekeruhan & NTU & Maks. 25 & 91,6 & 59,4 & 34,4 \\
\hline Parameter Kimia & & & & & \\
\hline Zat Besi (Fe) & $\mathrm{mg} / \mathrm{L}$ & Maks 1,0 & 0,210 & 0,113 & 0,554 \\
\hline Zat Organik $\left(\mathrm{KMnO}^{4}\right)$ & $\mathrm{mg} / \mathrm{L}$ & Maks 10 & 9,31 & 5,82 & 11,93 \\
\hline
\end{tabular}

Tabel 4 menunjukan kualitas air rawa pada sumur gali dengan parameter fisik (kekeruhan) di 3 titik melebihi ambang batas berdasarkan Permenkes No. 32/2017 dengan standar maksimal 25 NTU. Untuk parameter kimia pada Zat Besi (Fe) di 4 titik kurang dari ambang batas berdasarkan Permenkes No. $32 / 2017$ sebesar $1,0 \mathrm{mg} / \mathrm{L}$. Untuk parameter kimia (Zat Organik $\left(\mathrm{KMnO}^{4}\right)$ ada titik 1 dan titik 2 yang nilai ambang batas kurang dari batas maksimal $10 \mathrm{mg} / \mathrm{L}$, titik 3 sebesar $11,93 \mathrm{mg} / \mathrm{L}$ melebihi ambang batas Permenkes No. 32/2017.

Tabel 5 Hasil pemeriksaan Parameter Fisik dan Kimia pada Air Rawa Sumur Bor berdasarkan Kekeruhan, Kadar Besi (Fe), dan Kandungan Zat Organik (KMnO4)

\begin{tabular}{|c|c|c|c|c|c|c|}
\hline \multirow{2}{*}{ Paramaeter } & \multirow{2}{*}{ Satuan } & \multirow{2}{*}{$\begin{array}{c}\text { Syarat Mutu } \\
\text { Permenkes No. 32/2017 }\end{array}$} & \multicolumn{4}{|c|}{ Sampel Air Rawa (Sumur Bor) } \\
\hline & & & Titik 1 & Titik 2 & Titik 3 & Titik 4 \\
\hline $\begin{array}{l}\text { Parameter Fisik } \\
\text { Kekeruhan } \\
\text { Parameter Kimia }\end{array}$ & NTU & Maks. 25 & 8,94 & 8,44 & 0,79 & 1,09 \\
\hline Zat Besi & $\mathrm{mg} / \mathrm{L}$ & Maks 1,0 & 0,160 & 0,087 & 0,091 & 0,096 \\
\hline Zat Organik $\left(\mathrm{KMnO}^{4}\right)$ & $\mathrm{mg} / \mathrm{L}$ & Maks. 10 & 5,24 & 12,86 & 1,75 & 2,91 \\
\hline
\end{tabular}

Sumber : Hasil Uji Laboratorium BARISTAN (Januari, 2020)

Tabel 5 menunjukan kualitas air rawa pada sumur bor dengan parameter fisik pada kekeruhan di 4 titik kurang dari ambang batas berdasarkan Permenkes No. 32/2017 dengan standar maksimal 25 NTU. Untuk parameter kimia pada Zat Besi $(\mathrm{Fe})$ di 4 titik kurang dari ambang batas berdasarkan Permenkes No. 32/2017 sebesar $1,0 \mathrm{mg} / \mathrm{L}$. Untuk parameter kimia pada Zat Organik $\left(\mathrm{KMnO}^{4}\right)$ ada titik 1, titik 3 dan titik 4 yang nilai ambang batas kurang dari batas maksimal $10 \mathrm{mg} / \mathrm{L}$, sedangkan di titik 2 sebesar $12,86 \mathrm{mg} / \mathrm{L}$ melebihi ambang batas Permenkes No. 32/2017.

\section{PEMBAHASAN}

\section{Karakteristik Pengguna Air Rawa}

Pengguna air rawa adalah orang-orang yang menggunakan air permukaan atau air tanah yang terdapat di daerah pasang surut, dataran rendah, berwarna merah kecoklatan, berasa asam dan memiliki kandungan zat organik tinggi. Karakteristik responden yang berdasarkan pekerjaan masyarakat terbanyak dalam menggunakan air rawa antara yaitu tidak bekerja yakni sebanyak 26 orang (76,5\%), pada umumnya yang tidak bekerja adalah ibu rumah tangga yang paling sering berada dirumah untuk memenuhi keperluan rumah dan keluarga dan ibu rumah tangga juga paling sering menggunakan air rawa untuk keperluan sehari-hari seperti mencuci, memasak dan lain sebagainya. Responden yang bekerja sebagai petani umumnya adalah laki-laki sedangkan bagi perempuan mereka sebagai ibu rumah tangga saja yang bertugas mengurusi rumah dan keluarga.

\section{Kualitas Fisik (Kekeruhan)}

Berdasarkan hasil penelitian yang dilakukan di Desa Banyu Hirang diketahui bahwa 3 titik sumur gali melebihi ambang batas. Sedangkan pada sumur bor masuk dalam kurang dari ambang batas. Air yang keruh berarti mengandung bahan-bahan lain yang berbahaya bagi kesehatan, misalkan pada air rawa yang berwarna kuning atau coklat bahwa air rawa bila dihirup maka terasa bau, air yang baik merupakan ciri tidak berbau bila dihirup. Semakin keruh menunjukan semakin banyak butir-butir tanah dan kotoran yang terkandung di dalamnya. Air yang berkualitas harus memenuhi syarat fisik seperti berikut jernih atau tidak keruh. Air yang keruh disebabkan oleh adanya butiran-butiran dari bahan tanah liat. Semakin banyak kandungan tanah liat maka air semakin keruh. 
Kekeruhan merupakan banyaknya zat tersuspensi pada suatu perairan. Kekeruhan dapat disebabkan oleh berbagai jenis material tersuspensi, semakin banyak material yang tersuspensi maka air akan semakin terlihat keruh. Nilai kekeruhan dinyatakan dalam Nephelometric Turbidity Unit (NTU).

Hasil pemeriksaan kualitas air terhadap parameter kekeruhan sebagian besar sudah memenuhi standar kualitas kekeruhan yang di tetapkan PERMENKES NOMOR 492/MENKES/PER/1V/2010 yaitu kekeruhan untuk kualitas air minum maksimal 5 NTU, namun pada keadaan tertentu masih ada kekeruhan yang belum memenuhi standar yang telah ditetapkan, karena kekeruhannya mencapai 16.7 NTU, namun jika dibandingkan dengan PERMENKES NO. 416/MENKES/PER/IX/1990 tentang kualitas air bersih kekeruhan tersebut masih memenuhi standar karena tidak melebihi 25 NTU (Sari dan Nurdiana, 2017).

Air dapat dikatakan keruh apabila air tersebut mengandung banyak partikel-partikel yang tersuspensi sehingga memberikan warna yang kotor. Kekeruhan air dapat ditimbulkan oleh berbagai hal diantaranya dari bahan organik maupun anorganik yang terkandung di dalam air misal lumpur dan bahan yang dihasilkan oleh buangan industri yang sangat menggangu proses pengolahan air. Oleh karena itu pengendalian air sangat dibutuhkan dalam proses pengolahan air agar air tersebut layak digunakan untuk proses selanjutnya. Kekeruhan merupakan banyaknya zat yang tersuspensi pada suatu perairan

Konsentrasi kekeruhan air Sungai Pakerisan yang dilakukan di lokasi hulu sebesar 0,8 NTU di lokasi tengah sebesar 16,7 NTU dan di lokasi hilir sebesar 7,6 NTU. Konsentrasi kekeruhan di wilayah tengah tinggi karena padatan tersuspensi seperti pasir, tanah liat, bahan-bahan organik yang dibawa oleh limbah lebih banyak. Semakin tinggi padatan tersuspensi semakin tinggi nilai kekeruhan. Apabila kekeruhan tinggi maka kandungan oksigen akan menurun (Asrini, Adnyana dan Rai, 2017).

Menurut penelitian (Said et al., 2019), menyatakan bahwa, Karbon aktif juga dapat memperbaiki warna dan kekeruhan air gambut menjadi lebih jernih, hal ini disebabkan oleh zat organik pada air gambut masuk ke dalam pori karbon aktif sebagai adsorben. Kekeruhan air disebabkan oleh zat padat yang tersuspensi, baik yang bersifat anorganik yang berasal dari pelapukan batuan dan logam maupun organik yang berasal dari lapukan tanamanatau hewan yang dapat menjadi makanan bakteri, sehingga mendukung perkembangbiakannya (Suhendra, Marsaulina dan Santi, 2013).

\section{Kualitas Kimia (Zat Besi (Fe) dan (Zat Organik $\left.\left(\mathrm{KMnO}_{4}\right)\right)$}

Air rawa adalah air yang digunakan warga untuk keperluan sehari-hari untuk beraktivitas. Sampel air ini diambil pada sumur di rumah-rumah warga Desa Banyu Hirang secara random, 3 titik sampel berasal dari air sumur gali, 4 titik sampel berasal dari air pada sumur bor kemudan sampel air ini dibawa ke BARISTAND (Balai Riset dan Standarisasi Industri) Kota Banjarbaru untuk dilakukan pemeriksaan kualitas fisik dan kimia air rawa. Air rawa mengandung senyawa organik terlarut yang menyebabkan air menjadi berwarna coklat dan bersifat asam, Sehingga perlu pengolahan khusus sebelum siap untuk dikonsumsi.

Keberadaan zat besi dalam air dapat menyebabkan air menjadi berwarna, berbau dan berasa. Sebanyak 3 responden (15\%) menyatakan bahwa air sumur galinya berbau amis dan berwarna merah kekeruhan. Kadar besi yang berlebihan selain dapat menyebabkan timbulnya warna merah juga dapat menyebabkan karat pada peralatan yang terbuat dari logam (Munfiah, Nurjazuli dan Setiani, 2013).

Menurut penelitian (Shaleh, Mas'ud dan Permana, 2018), menyatakan bahwa dari uji Besi (Fe) pada air sumur artetis sebagai air bersih yang telah dilakukan oleh Balai Laboratorium Dinas Kesehatan Propinsi Jawa Timurr, hasil Besi $(\mathrm{Fe})$ dalam air sumur artetis adalah 2,06mg/L (Tidak Normal) tidak layak atau melebihi nilai baku mutu dari Permenkes No:416/Menkes/Per /IX/1990 adalah 1,0mg/L. Kandungan besi dalam air sumur artetis melebihi baku mutu sehingga dapat menimbulkan warna (kuning) dan rasa, pengendapan pada dinding pipa, pertumbuhan bakteri besi dan kekeruhan

Hasil pengukuran kandungan besi di Sungai Kaliyasa diketahui sebesar $2 \mathrm{mg} / \mathrm{L}$ melebihi baku mutu $(1,0 \mathrm{mg} / \mathrm{L})$, dan berakibat pada tingginya kandungan besi pada sumur terdekat. Sehingga kelebihan zat $\mathrm{Fe}$ bisa menyebabkan keracunan, dimana terjadi muntah, diare, kerusakan usus, hemokromatosis, sirosis, kanker hati, diabetes, gagal jantung, artritis, impotensi, kemandulan, hopotiroid, dan kelelahan menahun (Marwati dkk, 2008 dalam Sasongko, 2014).

Berdasarkan hasil analisis sampel dipemukiman titik 5 permukiman dekat rawarawa, bahwa kadar besi $(\mathrm{Fe})$ yaitu $0,35 \mathrm{mg} / \mathrm{L}$, 
tingginya kadar besi $(\mathrm{Fe})$ pada lokasi ini disebabkan oleh akibat proses dekomposisi bahan organik yang berlebihan kemudian meresap didalam tanah dan mengalir melalui aliran tanah yang kemudian masuk kedalam sumur penduduk yang menyebabkan kadar besi $(\mathrm{Fe})$ sangat tinggi (Destiquama, Hasriyanti dan Amal, 2019)

Zat organik diidentifikasikan sebagai Angka permanganate yaitu banyaknya $\mathrm{mg} / \mathrm{L}$ (KMnO4) yang dibutuhkan untuk mengoksidasi zat organik yang terdapat dalam satu liter sampel air yang didihkan selama 10 menit. Untuk kebutuhan minum air harus bebas dari logam berat, zat organik maupun mikroorganisme yang dapat membahayakan tubuh manusia. Untuk mengantisipasi hal tersebut maka disarankan penggunaan air harus direbus terlebih dahulu untuk menghindari terjadinya penyakit yang disebabkan oleh air.

Berdasarkan penelitian (Ningrum, 2018), menunjukkan bahwa hasil pemeriksaan kualitas air sumur terdapat satu parameter yang belum sesuai dengan parameter Peraturan Kemenkes No: 416/ MENKES/PER/IX/1990 tentang Syaratsyarat dan Pengawasan Kualitas Air yaitu parameter zat organik. Kadar zat organik yang belum memenuhi baku mutu pada sampel sumur 4 dan 6, serta terdapat parameter zat organik yang mendekati batas maksimal yang ditentukan. Zat organik yaitu zat yang pada umumnya merupakan bagian dari binatang atau tumbuh tumbuhan dengan komponen utamanya karbon, protein, dan lemak lipid. Zat organik ini mudah sekali mengalami pembusukan oleh bakteri dengan menggunakan oksigen terlarut. Zat organik yang ada dalam air berasal dari alam atau sebagai dampak dari kegiatan manusia.

Adanya bahan-bahan organik dalam air akan menyebabkan timbulnya warna, bau dan rasa dan kekeruhan dalam air. Pengaruh terhadap kesehatan adanya zat organik dalam air minum yang melebihi baku mutu dapat menyebabkan sakit perut. Hasil penelitian menunjukkan kadar zat organik 1,67$14,85 \mathrm{mg} / \mathrm{L}$. Kadar zat organik air sumur bor 1,37-14,53mg/L. Baku mutu kadar zat organik pada air bersih dan air minum adalah $10 \mathrm{mg} / \mathrm{L}$. Sebanyak 10 sumur gali (50\%) dan 1 sumur bor $(5 \%)$ dengan kadar zat organik yang melebihi baku mutu air bersih dan air minum. Tingginya kadar zat organik ini dapat berasal dari cemaran jamban, limbah rumah tangga dan tempat pembuangan sampah (Munfiah, Nurjazuli dan Setiani, 2013).

\section{Keluhan Kesehatan Pengguna Air Rawa}

Berdasarkan hasil penelitian yang dilakukan dapat diketahui bahwa dari 34 reponden. Keluhan pada kesehatan kulit seperti gatal-gatal sebanyak 25 responden (73\%) pada saat menggunakan air rawa. Semakin sering responden mandi di air rawa maka semakin banyak gatal-gatal atau panu yang dialami oleh responden, terlebih pada anak-anak. Keluhan gatal-gatal ini pada umumnya berada di bagian belakang badan. Karena adanya kandungan zat yang terdapat dalam air dan sarana air bersih. Dalam kondisi seperti ini tidak ada pilihan lain pada daerah tersebut selain air rawa yang digunakan untuk sehari-hari.

Desa Banyu Hirang merupakan daerah yang krisis sumber air bersih sehingga rentan terhadap penyakit kulit. Keluhan kesehatan yang dialami responden akibat penggunaan air rawa dapat berdampak langsung seperti diare, gatalgatal tetapi ada juga yang berdampak tidak langsung dalam jangka waktu puluhan tahun karena akumulasi unsur-unsur kimia yang terdapat pada tubuh yang memerlukan pemeriksaan lebih mendetail untuk mengetahui dampak jangka panjang tersebut seperti kerusakan pada hati dan ginjal. Keluhan kesehatan yang lain seperti keluhan terhadap saluran pencernaan, menyatakan bahwa keluhan yang sering dirasakan adalah diare sebanyak 20 orang $(59 \%)$. Diare dapat juga disebabkan karena air gambut yang mengandung kadar $\mathrm{Fe}$ yang tingggi seperti yang telah dijelaskan sebelumnya bahwa kadar Fe yang tinggi di dalam tubuh dapat merusak dinding usus yang bersifat iritan bagi saluran gastrointestinal menimbulkan diare.

Berdarkan hasil penelitian (Talipi, Joseph dan Kandou, 2016), menyatakan bahwa hasil yang didapat yang menjawab mempunyai keluhan yaitu 3 orang dimana keluhan kesehatan yang dirasakan yaitu diare sedangkan keluhan mata merah hanya 1 orang dan yang menjawab tidak memiliki keluhan kesehatan yaitu sebanyak 56 orang. penyakit yang menyerang manusia dapat ditularkan dan menyebar secara langsung maupun tidak langsung melalui air. Kira-kira terdapat 20 sampai 30 macam penyakit infektif yang dapat dipengaruhi oleh perubahan penyediaan air.

Berdasarkan hasil wawancara yang dilakukan terhadap 11 kepala keluarga yang dijadikan responden, diperoleh keterangan mengenai keluhan kesehatan di desa Lalong yaitu sebanyak $5(45,5 \%)$ yang mengalami keluhan selama 3 bulan terakhir, dan $6(54,5 \%)$ tidak 
mengalami keluhan kesehatan. Jenis keluhan kesehatan yang diderita yaitu untuk diare sebanyak $2(18,2 \%)$ responden yang mengalaminya. Untuk kulit gatal, merah, dan panas dialami oleh $3(27,3 \%)$ responden. dari 5 $(45,5 \%)$ responden yang mengalami keluhan kesehatan, terdapat 2 responden yang memiliki alergi akibat makanan (Naolana, 2013).

Gangguan kulit pada responden didapat dari hasil wawancara menggunakan kuesioner dan pemeriksaan fisik dengan tanda-tanda gatal pada kulit responden dalam waktu satu tahun terakhir. Hasil penelitian menunjukkan bahwa proporsi responden yang mengalami gangguan kulit sebanyak 45 orang (45\%). Keluhan subjektif didapat dari hasil wawancara menggunakan kuesioner untuk melihat keluhan kesehatan seperti mual $4 \%$, muntah $3 \%$, diare $10 \%$, keram otot $65 \%$, tremor $31 \%$, denyut jantung cepat $18 \%$, sakit kepala $54 \%$, pusing $64 \%$, telinga berdenging $17 \%$, cepat lelah $27 \%$, tekanan darah tinggi $27 \%$, serta kulit dan kuku kebiruan 0\% yang responden alami dalam waktu satu tahun terakhir (Sunarsih et al., 2018)

Keluhan kesehatan yang dialami responden akibat penggunaan air gambut ini dapat berdampak langsung seperti diare, gatal-gatal tetapi ada juga yang berdampak tidak langsung dalam artian dalam jangka waktu puluhan tahun karena akumulasi unsur-unsur kimia yang terdapat pada tubuh yang memerlukan pemeriksaan lebih mendetail untuk mengetahui dampak jangka panjang tersebut seperti kerusakan pada hati dan ginjal. Dalam observasi yang dilakukan pada penelitian ini hanya melihat

\section{DAFTAR PUSTAKA}

Agmalini, S., Lingga, N. N. dan Nasir, S. (2013). Peningkatan kualitas air rawa tanah liat alam dan abu terbang batubara. Jurnal Teknik Kimia, 19(2), hal. 59-68.

Asrini, N. K., Adnyana, I. W. S. dan Rai, I. N. (2017). Studi Anallisis Kualitas Air di Daerah Aliran Sungai Pakerisan Provinsi Bali. Jurnal Ecotrophic, 11(June). doi: 10.24843/EJES.2017.v11.i02.p01.

Destiquama, Hasriyanti dan Amal. (2019). Studi Kelayakan Air Tanah Untuk Kebutuhan Air Minum di Kelurahan Romang Polong Kecamatan Somba Opu Kabupaten Gowa. Jurnal Environmental Science, 2(492).

Hapsari, D. (2015). Kajian Kualitas Air Sumur Gali dan Perilaku Masyarakat di Sekitar Pabrik Semen Kelurahan Karangtalun Kecamatan Cilacap Utara Kabupaten keluhan kesehatan yang berdampak langsung pada responden. Selain diare, responden ada juga yang mengalami gatal-gatal sebesar $72,4 \%$. Setengah dari responden yang menjadi sampel mengalami gatal-gatal akibat penggunaan air gambut ini. Daerah yang terkena krisis sumber air bersih rentan terhadap penyakit kulit menular seperti gatal-gatal. Penyakit gatal-gatal dikarenakan minimnya pasokan sumber air bersih yang dimiliki yang hanya cukup untuk kebutuhan dapur saja (Suhendra, Marsaulina dan Santi, 2013).

\section{SIMPULAN}

Hasil uji laboratorium yaitu dari 7 sampel sumur antara lain 3 (tiga) sumur gali dan 4 (empat) sumur bor. Ditinjau dari parameter fisik (kekeruhan), kualitas kimia (kandungan zat organik (KMnO4)) pada sumur gali semuanya melebihi ambang batas menurut Syarat Mutu Permenkes No. 32/2017. Sedangkan pada kualitas kimia (zat besi $(\mathrm{Fe})$ ) kurang dari ambang batas yang ditetapkan. Untuk kualitas air pada sumur bor dari parameter fisik (kekeruhan), kualitas kimia (kandungan zat organik (KMnO4)) dari 4 titik kurang dari ambang batas berdasarkan Permenkes No. 32/2017 sedangkan 1 titik pada sumur bor terdapat parameter kualitas zat organik (KMnO4) melebihi ambang batas sebesar $12,86 \mathrm{mg} / \mathrm{L}$. Untuk keluhan kesehatan, masyarakat menyatakan mengalami ganguan kesaehatan berupa ganguan kesehatan pada kulit gatal-gatal dan pada saluran pencernaan mengalami diare.

Cilacap. Jurnal Sains dan Teknologi Lingkungan, 7(1), hal. 1-17.

Munfiah, S., Nurjazuli dan Setiani, O. (2013) Kualitas Fisik dan Kimia Air Sumur Gali dan Sumur Bor di Wilayah Kerja Puskesmas Guntur II Kabupaten Demak. Jurnal Kesehatan Lingkungan Indonesia, 12(2), hal. 154-159.

Naolana. (2013). Gambaran kualitas air sumur gali di sekitar lahan pertanian desa lalong kecamatan walenrang kabupaten luwu tahun 2013. [Skripsi]. Makassar: Universitas Islam Negeri Alauddin Makassar.

Ningrum, S. O. (2018). Analisis Kualitas Badan Air Dan Kualitas Air Sumur. Jurnal Kesehatan Lingkungan, 10(1), hal. 1-12.

Said, Y. M. et al. (2019). Karakteristik Fisika dan 
Kimia Air Gambut Kabupaten Tanjung Jabung Barat, Provinsi Jambi. Jurnal Sains dan Teknologi Lingkungan, 11(2), 132-142.

Sasongko, Budi Endar, Widyaastuti, E. dan Priyono Edy Rawuh. (2014). Kajian Kualitas Air Dan Penggunaan Sumur Gali Oleh Masyarakat Di Sekitar Sungai Kaliyasa Kabupaten Cilacap. Jurnal Ilmu Lingkungan. 12(2), hal 2-4.

Sari, A. P. dan Nurdiana, J. (2017). Pemantauan $\mathrm{pH}$, Kekeruhan dan Sisa Chlor Air Produksi di Laboratorium Mini IPA Cendana PDAM Tirta Kencana Kota Samarinda Kalimantan Timur. Jurnal Teknik Lingkungan, 1(1), hal. 4-7.

Shaleh, F. R., Mas'ud, F. dan Permana, T. A. (2018). Kajian Kualitas Air Sumur Sebagai Sumber Air Bersih di Kecamatan Babat Kabupaten Lamongan. Jurnal Grouper, 9(September), 1-11.

Suhendra, S. D., Marsaulina, I. dan Santi, N. D. (2013). Analisis Kualitas Air Gambut dan Keluhan Kesehatan Pada Masyarakat di Dusun Pulo Gombut Desa Suka Rame
Baru Kecamatan Kuala Hulu Kabupaten Batu Utara Tahun 2012. Jurnal Lingkungan dan Kesehatan Kerja, 2(3).

Permenkes RI. (2017). Peraturan Kementerian Kesehatan RI Nomor 32 tentang Standar Baku Mutu Kesehatan Lingkungan dan Persyaratan Kesehatan Air Untuk Keperluan Higiene Sanitasi, Kolam Renang, Solus Per Aqua, dan Pemandian Umum. Jakarta.

Sunarsih, E. et al. (2018). Analisis Paparan Kadmium , Besi , Dan Mangan Pada Air Terhadap Gangguan Kulit Pada Masyarakat Desa Ibul Besar Kecamatan Indralaya Selatan Kabupaten Ogan Ilir. Jurnal Kesehatan Lingkungan Indonesia, 17(32), 68-73.

Talipi, Y., Joseph, W. B. S. dan Kandou, G. D. (2016). Gambaran Kualitas Air Sumur Gali dan Keluhan Gangguan Kesehatan Penggunanya di Desa Kulu Kecamatan Wori Kabupaten MInahasa Utara Tahun 2016. Jurnal Media Kesehatan, 8(3), 1-7. 